\title{
The Permeable Character of CSG Dams and Their Seepage Fields
}

\author{
Xin Zhao $\mathbb{D}$ and Yunlong $\mathrm{He}$ \\ State Key Laboratory of Water Resources and Hydropower Engineering Science, Wuhan University, Wuhan 430072, China \\ Correspondence should be addressed to Yunlong He; ylhe2002@aliyun.com
}

Received 28 April 2018; Revised 27 June 2018; Accepted 11 July 2018; Published 14 October 2018

Academic Editor: Diyi Chen

Copyright (C) 2018 Xin Zhao and Yunlong He. This is an open access article distributed under the Creative Commons Attribution License, which permits unrestricted use, distribution, and reproduction in any medium, provided the original work is properly cited.

\begin{abstract}
Current studies regarding the permeable properties, corrosion properties, and seepage characteristics of cemented sand and gravel (CSG) materials are based on laboratory tests. Thus, there is a lack of studies analyzing the permeable character of seepage fields based on monitoring data from real prototypes working under practical operating conditions. In this paper, on the basis of measured data from the Dahuaqiao cofferdam, we establish an inversion analysis method for unsteady seepage fields covering different time periods within a time sequence. The results indicate an effective dynamic change law for the material permeability coefficient and the real dynamic evolution characteristics of seepage fields. The permeability coefficient of CSG exhibits a "selfhealing" phenomenon similar to concrete, with the seepage characteristics of a dam tending to become stable over time. Under the long-term action of water pressure, the seepage behavior of the dam body shows no obvious deterioration, suggesting that CSG can satisfy the required anticorrosion property expected of dam construction materials. Thus, abnormal CSG might serve as an effective antiseepage layer that can meet the running requirements of cofferdams. The results of this research can provide reference for further improvement in the CSG dam design theory.
\end{abstract}

\section{Introduction}

Cemented sand and gravel (CSG) dams are a new type of dam that have been developed in recent years. In 1992, Londe and Lino [1] first proposed that CSG could be rolled and dammed into symmetrical sections of upstream and downstream facing slopes $(0.7 \mathrm{H} / 1 \mathrm{~V})$ by using a particular kind of rolling and filling construction method. A waterproof panel could then be placed on just the upstream face to prevent seepage. This new type of dam not only has the potential to reduce damage to the environment but also offers a significant approach to updating dam design. On the basis of this, CSG dams have been developed in places as diverse as Japan, Turkey, Greece, the Dominican Republic, the Philippines, and China. To date, more than 30 CSG dams (including cofferdams) have been built or are under construction around the world. The first Marathia dam [2] was constructed in Greece in 1993 using a CSG-based approach, and work on the 100-meter-high Cindere dam in Turkey [3] began in 1994. The practice of building CSG dams began in China in 2004 but has been mainly limited to cofferdams. The only permanent project under construction is the Shoukoubao dam with a height of 61.4 meters [4].

CSG dams have the advantages of being environmentally friendly, using less glue material, being straightforward, and quick to construct, allowing for the easy control of temperature, being adaptable to soft foundations, and having excellent antiseismic performance [5]. However, because less cement is used (generally $40 \sim 60 \mathrm{~kg} / \mathrm{m}^{3}$, with the total glue material being $\left.80 \sim 100 \mathrm{~kg} / \mathrm{m}^{3}\right)$, there is not a high demand placed on construction technology, the independent strength of the dam materials is low, and their antiseepage properties are poor. Despite there being a dedicated antiseepage layer, seepage and corrosion can still occur. Two questions demanding in-depth study therefore arise: (1) is the long-term seepage and corrosion behavior of CSG dam materials resulting from water pressure capable of becoming stable? (2) Will the seepage characteristics of such dams deteriorate over time?

Generally, recent research on the seepage and corrosion characteristics of CSG has primarily focused on experimental studies. Chen et al. [6] have conducted an experimental study 
regarding the seepage and corrosion performance of CSG materials. They found that the $\mathrm{Ca}^{2+}$ concentration and the age curve first of all show a rising trend, with them then decreasing and finally stabilizing at a fixed value. Feng [7] used experiments to measure the change law of $\mathrm{Ca}^{2+}$ and its permeability coefficient along with its aging. The results suggest that the corrosion-resistant properties of CSG do not continually deteriorate, but rather stabilize. It was also inferred that the seepage path is mainly around weak areas like the interface. The calculation of seepage fields and inversion analysis of monitoring data can be carried out using related methods for calculating rock-soil bodies. Shao [8], for instance, presents an Incompressible smoothed particle hydrodynamics (ISPH) method to simulate wave interactions within a porous medium. Assuming an unstable seepage process, Li et al. [9] have made use of a BP neural network and a genetic algorithm to invert the permeability coefficient of the rock-soil body at the dam's foundation. Liu et al. [10] have studied the seepage field law for CSG dams by using a finite element simulation method. This was then used to determine a reasonable antiseepage and drainage system by comparing the seepage field law with different antiseepage and drainage measures. Both the Hongkou cofferdam and Cindere dam [11] have embedded strain gauges, pressure gauges, thermometers, and other monitoring instruments, but there is a lack of analysis of monitoring data arising from the deployment of real working prototypes under practical operating conditions.

The overflow cofferdam upstream of the Dahuaqiao hydropower station is the highest CSG cofferdam to have been constructed in China at present. It is built on the main stream of the Lancang River, and it handles a large designated water flow. A variety of monitoring instruments, including osmometers, have been buried in the cofferdam, and data has been collected intensively, thus providing a large amount of monitoring data that is open to analysis. In this paper, the real workings and permeability characteristics of the seepage fields around CSG dams are studied by using the seepage monitoring data of the Dahuaqiao cofferdam, together with a finite element numerical simulation approach. We discuss ways in which the design of these types of structures and their associated antiseepage systems can be optimized and improved and put forward some propositions regarding how the design theory of CSG dams can itself be further developed.

\section{The Antiseepage Design of the Dahuaqiao CSG Cofferdam}

2.1. Project Overview. The Dahuaqiao hydropower station is the sixth hydropower station to have been developed according to the cascade plan for the main upstream portion of the Lantsang River. Its CSG overflow cofferdam, at a height of $57.0 \mathrm{~m}$, is the highest CSG cofferdam so far constructed in China. The cofferdam's crest elevation above the riverbed is $1426.0 \mathrm{~m}$. The left bank abutment elevation is $1429.0 \mathrm{~m}$, and the right bank abutment elevation is $1427.0 \mathrm{~m}$. The cofferdam's crest is $7.0 \mathrm{~m}$ wide and about $125.0 \mathrm{~m}$ long. The elevation of the foundations is $1372.0 \mathrm{~m}$, and the maximum foundation width is $62.0 \mathrm{~m}$. The slope ratios for the upstream and downstream faces of the cofferdam are $1: 0.5$ and $1: 0.6$, respectively. The cofferdam did not need any transverse or longitudinal seams.

The designed service life of the cofferdam is 2.5 years, with a water retaining standard of 10 years for recurrent floods in the dry season at a corresponding flow rate of $2060 \mathrm{~m}^{3} / \mathrm{s}$. The overflow standard is for 20 years of recurrent floods throughout the year at a corresponding flow rate of $6950 \mathrm{~m}^{3} / \mathrm{s}$. The cofferdam fulfilled its overflow functionality through the flood seasons of 2015 and 2016. In the flood season of 2015, the maximum water level was $1427.36 \mathrm{~m}$, with the cofferdam crest water-head being $1.36 \mathrm{~m}$, the maximum flood flow $2390 \mathrm{~m}^{3} / \mathrm{s}$, and the over-cofferdam flow about $140 \mathrm{~m}^{3} / \mathrm{s}$. The over-cofferdam flow lasted from August 21 to August 23, with the maximum water level being reached on August 23. In the flood season of 2016, the maximum water level was $1430.26 \mathrm{~m}$, the cofferdam crest water-head was $4.26 \mathrm{~m}$, the maximum flood flow was $3670 \mathrm{~m}^{3} / \mathrm{s}$, and the over-cofferdam flow was about $1255 \mathrm{~m}^{3} / \mathrm{s}$. This time, the over-cofferdam flow lasted from July 9 to July 18 and from July 23 to July 31 , with the maximum water level occurring on July 15 . During its operation, the cofferdam was subjected to a number of crack assessments. The upstream antiseepage layer was found to have no obvious long penetrating cracks, and the crest and downstream face did not indicate any possibility of corrosion failure.

The underlying bedrock at the cofferdam foundation was medium-thick-layered quartz sandstone and slate. The rock structure was undeveloped, and there were no large-scale faults, though the integrity of the rock mass was poor. The bedrock located at the left and right banks of the cofferdam was mainly greyish-green slate. The side slope was stable overall, but some locally unstable blocks were still present. A geologist had indicated that the foundation rock located in the center of the cofferdam was better and close to being classifiable as class II. The foundation rock located at the two sides of the dam shoulder, however, was relatively poor, and the cofferdam face foundation was considered to be class III. The proposed elastic modulus and Poisson ratio parameters were $8-14 \mathrm{GPa}$ and $0.15-$ 0.24 , respectively. It was suggested that the Lugeon value in the base at a depth of $0-5 \mathrm{~m}$ should be $q=10 \mathrm{Lu}$ and that the Lugeon value for the base at depths of 5-10 m should be $q=5 \sim 10 \mathrm{Lu}$.

The compressive strength of the CSG material inside the dam at an age of 28 days was designed to be $3.5 \mathrm{MPa}$. The measured compressive strength was $10.3 \mathrm{MPa}$, and the axial compression intensity was $7.1 \mathrm{MPa}$, with the axial compression modulus being $14.4 \mathrm{GPa}$ and the antiseepage grade being above W3. The actual compressive strength obtained using inspection samples during the construction process was $5.89 \mathrm{MPa}$. For the abnormal CSG material, the compressive strength in the antiseepage layer at the age of 28 days was also designed to be $3.5 \mathrm{MPa}$, with an antiseepage grade of W5. On the basis of experiments, the compressive strength of the material according to different construction methods was $10 \sim 12.9 \mathrm{MPa}$ and the axial compression elastic modulus was $16.7 \mathrm{GPa}$, with an antiseepage 
grade that was above W5 and a permeability coefficient of $3.13 \times 10^{-8} \mathrm{~cm} / \mathrm{s}$.

2.2. Antiseepage Design. Abnormal CSG was being used as an antiseepage layer for the first time in the Dahuaqiao cofferdam, making the antiseepage structure and drainage measures significantly more straightforward than they had been in previous projects. The cofferdam's upstream face had an antiseepage layer made of abnormal (vibrated groutenriched) CSG. The thickness of the antiseepage layer was $1.0 \sim 2.0 \mathrm{~m}$. The fundamental face had an antiseepage layer made of abnormal CSG with a thickness of $0.6 \mathrm{~m}$. In the middle of the river bed, $4.0 \mathrm{~m}$ thick concrete was backfilled to a range of $15 \mathrm{~m}$. No antiseepage curtain was established for the foundations. There were also no drainage facilities behind the antiseepage layer and inside the dam.

In order to capture the actual seepage field conditions during construction and its subsequent operation, the seepage monitoring of the Dahuaqiao cofferdam involved observation in two separate places: inside the cofferdam and the cofferdam foundations. The main body of the monitoring took place inside the cofferdam's riverbed section and was divided across two monitoring elevation schemes: $\mathrm{P} 1-5 \sim \mathrm{P} 1-8$; and $\mathrm{P} 1-1 \sim \mathrm{P} 1-4$, which were positioned within the cofferdam's foundations. The antiseepage design and the layout of the osmometers are shown in Figure 1.

\section{Monitoring Data Gathered during the Cofferdam's Operation}

The construction team started pouring the Dahuaqiao cofferdam on February 27, 2015, and it was completed on June 2, 2015. The dam officially began to block water in late June and was completely submerged in the spring of 2017. Figures 2 and 3 show the monitoring data acquired at the dam's foundations and inside the dam. In this paper, we shall be analyzing the seepage pressure monitoring data collected between April 2015 and November 2016, which covers almost the whole construction and operating periods. In view of the novelty of the antiseepage structure design, it was very important to understand the rules governing the entire seepage field for the dam body and its foundations.

After sorting and analyzing the seepage monitoring data regarding the cofferdam for nearly two years, it was possible to conclude that the water-head inside the cofferdam was mostly affected by the upstream water level. The three osmometer water-heads at an elevation of $1398.8 \mathrm{~m}$ had good correlation with the upstream water level, with changes in the water-head inside the cofferdam slightly lagging behind the upstream water-level changes. The correlation between the osmometer at an elevation of $1411 \mathrm{~m}$ and the upstream water level was poor because the water-head changed suddenly during the early stages of operation. This may be because the selection of the base value in this case had not been undertaken properly. Whatever the reason, these waterhead values could not be used for analysis. During the two years of flood seasons, the infiltration line was higher inside the cofferdam, but the infiltration line decreased when the

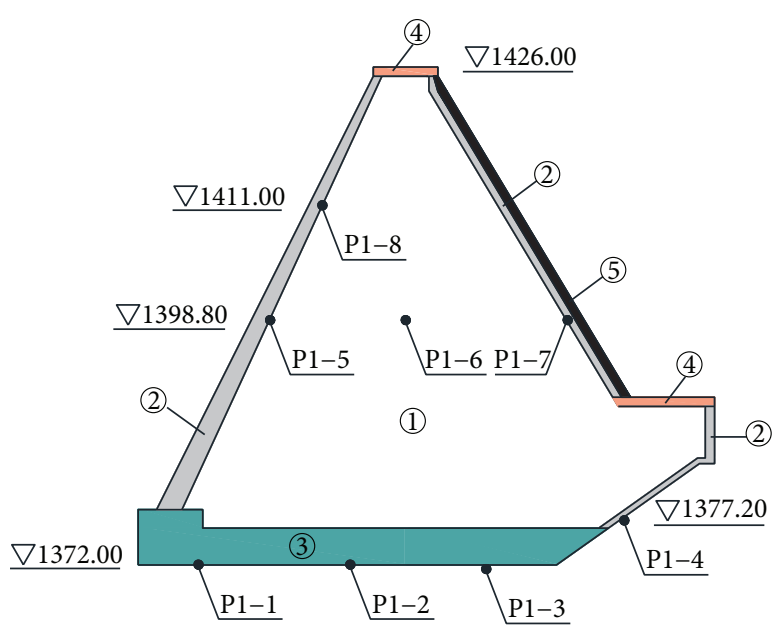
(1) CSG
(4) C20 concrete
(2) Abnormal CSG
(5) Precast concrete blocks
(3) $\mathrm{C} 15$ concrete

FIgURE 1: The antiseepage design and the layout of the osmometers.

foundation pit beyond the cofferdam began to be pumped and dredged. Obviously, the infiltration line decreased during the dry season. As a result of the lack of drainage holes, the water-head at the upstream side was higher than the downstream side at the same elevation.

The P1-5 monitoring points were close to the upstream antiseepage layer. It was found that the antiseepage effect of the antiseepage layer varied over time and according to the upstream water level. During the first water-level fluctuation event between June 2015 and July 2015, the range of variation for the osmometer water-head was small and, at this time, the antiseepage effect of the antiseepage layer was relatively strong. During the second water-level fluctuation event in the flood season between August and September, the osmometer water-head rose rapidly and remained at a high level, with the antiseepage effect of the antiseepage layer starting to wane. After this, the effect of the antiseepage layer basically remained stable.

The trend in the variation of the dam foundation's uplift pressure was basically consistent with that of the upstream water level of the cofferdam. The relationship between the uplift pressure and the upstream water level became even stronger after the flood season of 2015. In view of the lack of curtain grouting or drainage facilities, the dam foundation was subjected to a high uplift pressure, with the pressure decreasing from upstream to downstream.

\section{The Permeability Coefficient Inversion of CSG Material}

4.1. The Seepage Control Equation and the Finite Element Solution. Inversion analysis of the permeability coefficient should reflect the dynamic evolution of the seepage field relating to boundary water-level conditions, the seepage calculation area, and the changing seepage characteristics of the dam. Inversion analysis of the seepage field therefore 


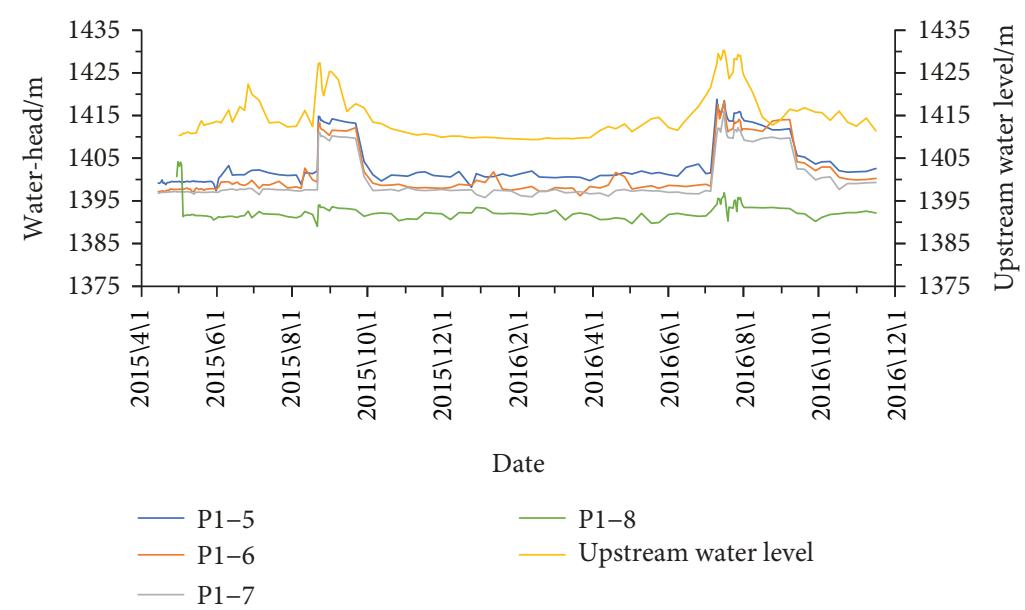

Figure 2: The water-head hydrograph for the measurement points inside the cofferdam.

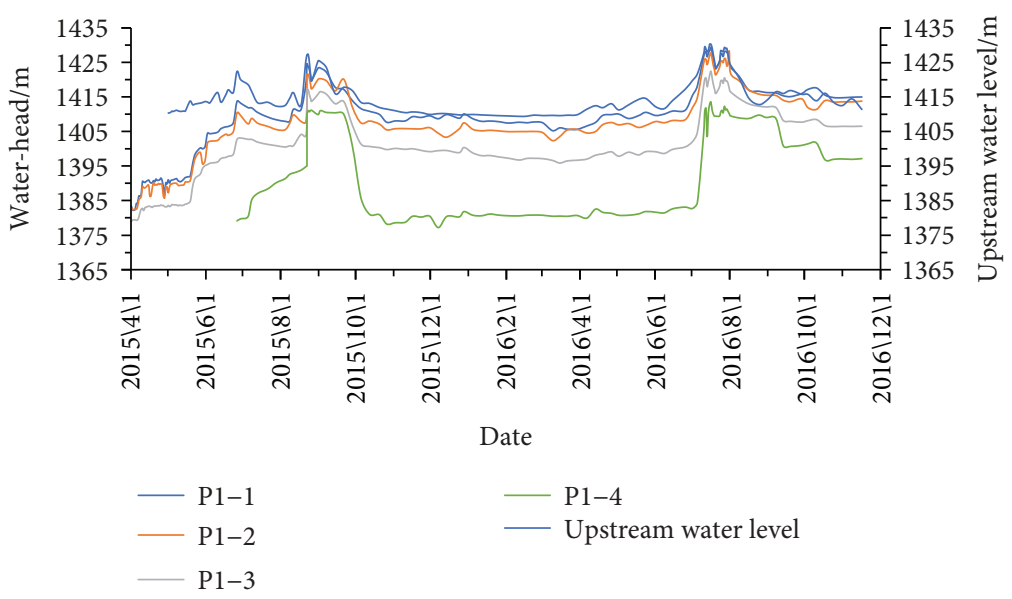

Figure 3: The water-head hydrograph for the measurement points at the cofferdam foundations.

needs to be based on an unsteady seepage model. The differential equation for an unsteady seepage field [12] is

$$
\frac{\partial}{\partial x}\left(k_{x} \frac{\partial H}{\partial x}\right)+\frac{\partial}{\partial y}\left(k_{y} \frac{\partial H}{\partial y}\right)+\frac{\partial}{\partial z}\left(k_{z} \frac{\partial H}{\partial z}\right)=S_{S} \frac{\partial H}{\partial t} .
$$

The initial condition was

$$
H(x, y, z, t)=H_{0}\left(x, y, z, t_{0}\right) .
$$

The boundary conditions were

$$
\begin{aligned}
& \left.H\right|_{\Gamma_{1}}=f(x, y, z, t) ;\left.\frac{\partial H}{\partial n}\right|_{\Gamma_{2}}=-\frac{v_{n}}{k_{n}}, \\
& \left.H\right|_{\Gamma_{3}}=z ;\left.v_{n}\right|_{\Gamma_{3}}=\mu \frac{\partial H}{\partial t} \cos \theta,
\end{aligned}
$$

where $H$ is the water-head distribution of the seepage field; $k_{x}, k_{y}$, and $k_{z}$ are the permeability coefficients in different directions; $S_{S}$ is the unit storage quantity; $n$ is the outer normal direction; $\mu$ is the specific yield in the variation range of the free surface; $\theta$ is the angle between the normal line of the free face and the lead line; $\Gamma_{1}$ is the first type of water-head boundary; $\Gamma_{2}$ is the second type of flow boundary; and $\Gamma_{3}$ is the free surface boundary, except in the first of the boundary conditions, where it still needs to meet the flowsupply relationship of the second boundary.

For CSG, its compressibility can be ignored, so $S_{S}=0$. In that case, (1) changes to

$$
\frac{\partial}{\partial x}\left(k_{x} \frac{\partial H}{\partial x}\right)+\frac{\partial}{\partial y}\left(k_{y} \frac{\partial H}{\partial y}\right)+\frac{\partial}{\partial z}\left(k_{z} \frac{\partial H}{\partial z}\right)=0
$$

When carrying out a finite element calculation, according to the variation principle, the above problem is equivalent to solving the following functional minimum value problem

$$
\begin{aligned}
I^{e}(T)= & \iiint_{V}\left\{\frac{1}{2} k_{x}\left(\frac{\partial H}{\partial x}\right)^{2}+k_{y}\left(\frac{\partial H}{\partial y}\right)^{2}+k_{z}\left(\frac{\partial H}{\partial z}\right)^{2}\right\} \\
& \cdot \mathrm{d} x \mathrm{~d} y \mathrm{~d} z+\iint_{\Gamma_{2}} q H \mathrm{~d} s,
\end{aligned}
$$




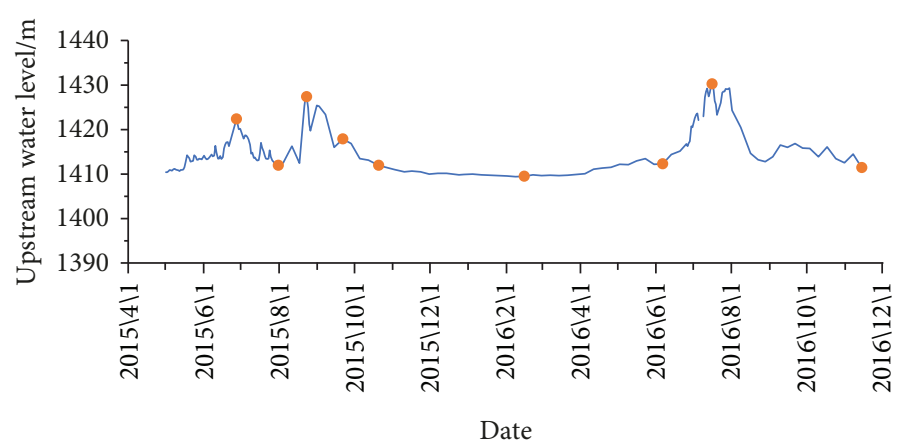

FIgURE 4: The moments chosen to conduct inversion calculation.

where $V$ is the subdomain unit $e$ of the intersolution domain, $\Gamma_{2}$ is the boundary of known flow, and $q$ is the corresponding flow.

The finite element discretization was carried out in a three-dimensional space domain, and an implicit difference was adopted in the time domain. The finite element solution equation can therefore be expressed as follows:

$$
\left([K]+\frac{1}{\Delta t}[P]\right)\{H\}_{t+\Delta t}-\frac{1}{\Delta t}[P]\{H\}_{t}=\{F\}
$$

where $[K]$ is the permeability coefficient matrix, $[P]$ is the flow matrix, and $[F]$ is the known constant term, which was obtained from the known node water-head.

\subsection{Inversion of the Permeability Coefficient}

4.2.1. Inversion Method. It was noted in Section 4.1 that, to serve as inversion parameters, the parameters used to calculate an unsteady seepage flow for a CSG dam need to include the permeability coefficient and the specific yield of the material. However, the variation of the specific yield was much smaller than the permeability coefficient. For an unconfined seepage problem in hydropower engineering, the influence of the specific yield on the seepage field is also small. This being so, only the permeability coefficient was used for the inversion parameters. For the Dahuaqiao cofferdam, the parameters for inversion were the permeability coefficient of CSG $k c$ and the permeability coefficient of abnormal CSG ke.

At present, inversion analysis of the permeability coefficient of rock and soil is mostly based on observational data at a certain time. However, there is little reported regarding inversion analysis based on time series data. In view of the dynamic feedback associated with seepage characteristics, this is an issue. For CSG dams, determination of the permeability coefficient of the material is still at a laboratory stage, so it is necessary to make full use of time series water-head data measured by osmometers to reflect the dynamic evolution characteristics of a seepage field. There is also a need for a dynamic change law for permeability coefficients over operational periods when conducting inversion of a seepage field. In view of these issues, the reliability of inversion results for seepage fields could be improved.
Considering the changes in the upstream water level over the operational period, a number of moments were selected (see Figure 4) to serve as the basis for a curve characterizing the water level that could encompass the highest water level in the flood season and the lowest water level in the dry season. In order to obtain real seepage parameters, understand changes in the CSG and seepage over time, and grasp the shifting trends in the seepage characteristics of CSG dams, it was necessary to conduct separate inversions for short periods before and after each selected point in time. The inversion parameters for each period were plotted onto curves, which could then provide the permeability coefficients with high precision and enable an analysis of seepage flow for different periods.

In this paper, in addition to the finite element analysis, the P1-5 P1-7 monitoring points at an elevation of $1398.8 \mathrm{~m}$ were used as a source for measured data during an inversion calculation. In this complex method, the isotropous permeability coefficient of CSG $k c$ and the permeability coefficient of abnormal CSG $k e$ were used as inversion parameters. The method was able to establish objective functions according to the error between measured water-head values and the output values of the finite element program. Thus, the seepage parameter inversion problem could be converted into a nonlinear optimization problem.

4.2.2. Calculation Model. Using the dam and geological data, a whole 3D finite element model of the Dahuaqiao cofferdam was created to carefully simulate the partitioning inside the dam. By referring to the operational records and monitoring data, the real water retention and flow processes during the flood season were also simulated. The overall finite element model grid is shown in Figure 5. There were a total of 58530 units and 66300 nodes. The permeability coefficient of the concrete used to fill the pond and pour the dam crest was taken to be $1 \times 10^{-9} \mathrm{~cm} / \mathrm{s}$ on the basis of related projects. The permeability coefficient for the foundations was taken to be $5 \times 10^{-5} \mathrm{~cm} / \mathrm{s}$ on the basis of the geological survey data.

4.3. Verification of the Results. The calculated values and measured values for the water-head according to certain water-level characteristics are compared in Table 1. At these inversion time points, the calculated values for the waterhead largely tally with the measured values and the inversion calculation accuracy is relatively good. After getting the 


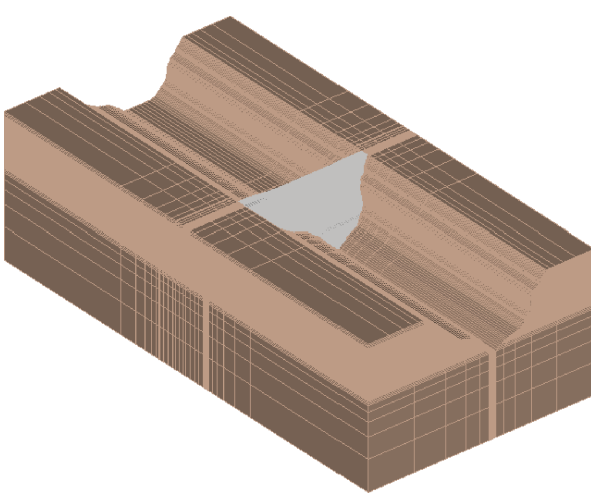

(a)

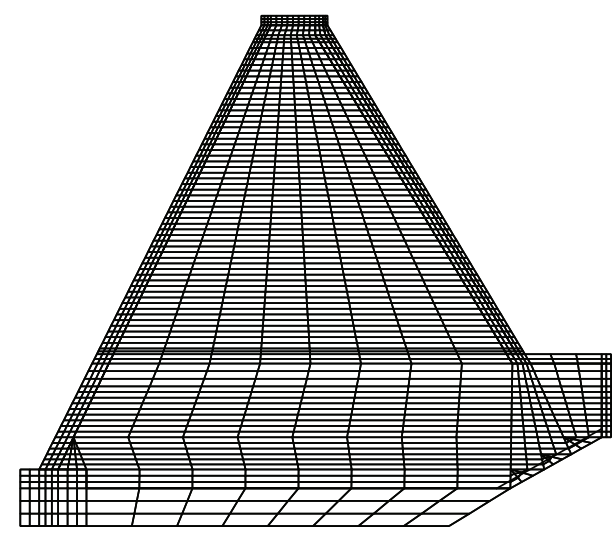

(b)

Figure 5: Finite element model of the cofferdam. (a) The overall model and (b) grid diagram of the cross section of the cofferdam body.

TABLE 1: The inversion results according to various water-level characteristics.

\begin{tabular}{|c|c|c|c|c|c|c|c|}
\hline \multirow[t]{2}{*}{ Date } & \multirow[t]{2}{*}{ Measuring point } & \multicolumn{2}{|c|}{ Water-head (m) } & \multirow[t]{2}{*}{ Error $(\mathrm{m})$} & \multicolumn{2}{|c|}{$\begin{array}{c}\text { Permeability coefficient } \\
(\mathrm{cm} / \mathrm{s})\end{array}$} & \multirow[t]{2}{*}{ Water-level characteristic } \\
\hline & & Calculated value & Measured value & & Normal CSG & Abnormal CSG & \\
\hline \multirow{3}{*}{$2015-6-27$} & $\mathrm{P} 1-5$ & 1402.15 & 1401.98 & 0.17 & \multirow{3}{*}{$1.00 \times 10^{-3}$} & \multirow{3}{*}{$1.18 \times 10^{-5}$} & \multirow{3}{*}{$\begin{array}{l}\text { Highest water-level } \\
\text { difference between upstream } \\
\text { and downstream in } 2015\end{array}$} \\
\hline & $\mathrm{P} 1-6$ & 1399.16 & 1399.45 & -0.29 & & & \\
\hline & $\mathrm{P} 1-7$ & 1397.37 & 1397.89 & -0.52 & & & \\
\hline \multirow{3}{*}{$2015-8-23$} & $\mathrm{P} 1-5$ & 1414.71 & 1414.59 & 0.12 & \multirow{3}{*}{$6.18 \times 10^{-3}$} & \multirow{3}{*}{$8.97 \times 10^{-5}$} & \multirow{3}{*}{$\begin{array}{l}\text { Highest upstream water } \\
\text { level in } 2015\end{array}$} \\
\hline & $\mathrm{P} 1-6$ & 1412.55 & 1412.88 & -0.33 & & & \\
\hline & $\mathrm{P} 1-7$ & 1410.40 & 1410.87 & -0.47 & & & \\
\hline \multirow{3}{*}{$2016-2-15$} & $\mathrm{P} 1-5$ & 1400.98 & 1401.35 & -0.37 & \multirow{3}{*}{$2.98 \times 10^{-3}$} & \multirow{3}{*}{$7.74 \times 10^{-5}$} & \multirow{3}{*}{ Lowest water level } \\
\hline & $\mathrm{P} 1-6$ & 1398.42 & 1397.83 & 0.59 & & & \\
\hline & $\mathrm{P} 1-7$ & 1397.32 & 1396.64 & 0.68 & & & \\
\hline \multirow{3}{*}{ 2016-7-1 } & $\mathrm{P} 1-5$ & 1401.55 & 1401.45 & 0.1 & \multirow{3}{*}{$6.35 \times 10^{-3}$} & \multirow{3}{*}{$6.73 \times 10^{-5}$} & \multirow{3}{*}{$\begin{array}{c}\text { Highest water-level difference } \\
\text { between upstream and } \\
\text { downstream in } 2016\end{array}$} \\
\hline & P1-6 & 1398.83 & 1398.92 & -0.09 & & & \\
\hline & $\mathrm{P} 1-7$ & 1397.34 & 1397.43 & -0.09 & & & \\
\hline \multirow{3}{*}{$2016-7-16$} & $\mathrm{P} 1-5$ & 1418.95 & 1418.48 & 0.47 & \multirow{3}{*}{$9.96 \times 10^{-3}$} & \multirow{3}{*}{$9.78 \times 10^{-5}$} & \multirow{3}{*}{$\begin{array}{l}\text { Highest upstream water } \\
\text { level in } 2016\end{array}$} \\
\hline & $\mathrm{P} 1-6$ & 1417.64 & 1418.25 & -0.61 & & & \\
\hline & $\mathrm{P} 1-7$ & 1415.93 & 1416.02 & -0.09 & & & \\
\hline
\end{tabular}

change trends for the permeability coefficients of the CSG materials and the seepage time by inversion according to the characteristics' time points, the calculated values and measured values for the water-head across the whole seepage process were compared (see Figure 6). Except for factors such as rainfall in the flood season, which could lead to significant differences over localized periods of time, the change laws at the three measured points were more or less the same. This indicates that the dynamic variation law for the permeability coefficients obtained by inversion is also comparatively accurate.

According to the on-site pumping records for the waterretention period, the seepage discharge was estimated to be about $36.1 \mathrm{~L} / \mathrm{s}$ according to the capacity and operating time of the water-pumping equipment. This makes up about half of the foundation seepage. The calculated seepage discharge was about $20 \sim 30 \mathrm{~L} / \mathrm{s}$ in the flood seasons, and that of the dry seasons was about $11 \sim 13 \mathrm{~L} / \mathrm{s}$. The calculated results for the seepage discharge are consistent with the observed and measured values at the construction site.

\section{Analysis of the Real Cofferdam Seepage Field Law}

5.1. The Dynamic Variation Law for Permeability Coefficients. The permeability coefficient for materials studied in experiments undertaken elsewhere [13] was in the region of $10^{-3} \sim 10^{-5} \mathrm{~cm} / \mathrm{s}$. However, the test values for the permeability coefficients arrived at in domestic laboratory experiments (see Table 2 ) are generally small, in the region of $10-6 \sim 10-8 \mathrm{~cm} / \mathrm{s}$, with an antiseepage level greater than or equal to W3. These experiments suggest that CSG material with uniform vibrated compaction properties has a good antiseepage performance. However, it remains the case that, in actual construction processes, the properties and construction characteristics of CSG materials make it difficult to 


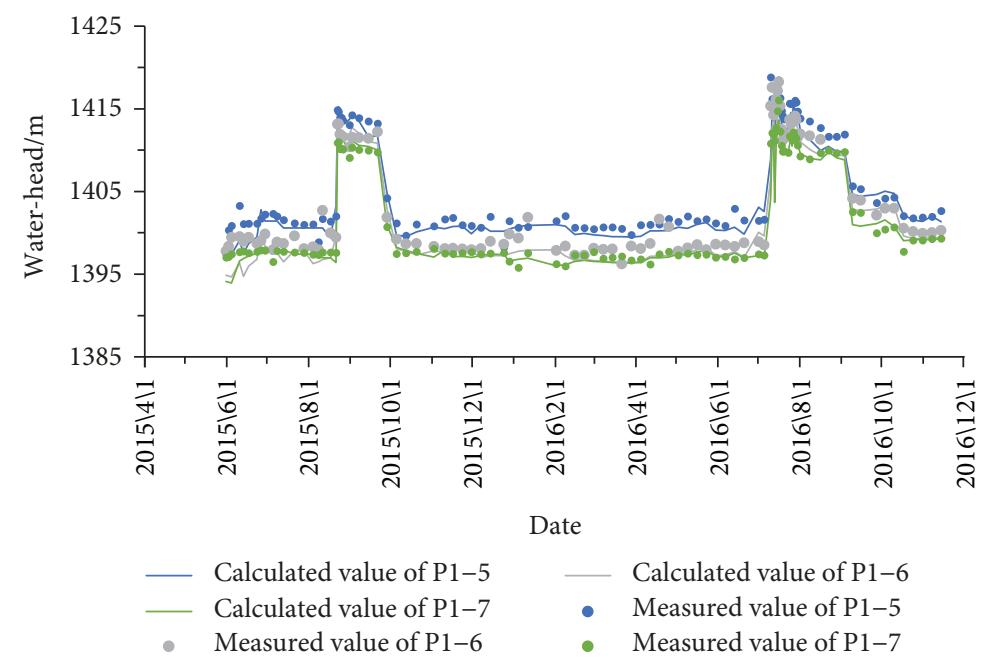

FIGURE 6: Water-head variation over time.

TABLE 2: Test values regarding the antipermeability coefficient of CSG materials.

\begin{tabular}{|c|c|c|c|c|}
\hline & Curing age $(\mathrm{d})$ & Permeability coefficient $(\mathrm{cm} / \mathrm{s})$ & Specimen size $(\mathrm{mm})$ & Specimen grading \\
\hline Experiment 1 [14] & 28 & $1.86 \times 10^{-8}$ & $\varphi 450 \times 450$ & $\begin{array}{l}\text { Full grading with maximum } \\
\text { particle size of } 40 \mathrm{~mm}\end{array}$ \\
\hline Experiment 2 [15] & & $4.66 \times 10^{-6} \sim 8.95 \times 10^{-5}$ & & \\
\hline Experiment 3 [16] & 43 & $\begin{array}{l}2.82 \times 10^{-8} \\
3.42 \times 10^{-8}\end{array}$ & $\begin{array}{c}300 \times 300 \times 300 \\
\varphi 450 \times 450\end{array}$ & $\begin{array}{l}\text { Wet-screened-out particles } \\
\text { with size larger than } 100 \mathrm{~mm}\end{array}$ \\
\hline \multirow[b]{2}{*}{ Experiment 4 [7] } & \multirow[b]{2}{*}{43} & $2.66 \times 10^{-8} \sim 5.08 \times 10^{-8}$ & $300 \times 300 \times 300$ & $\begin{array}{l}\text { Wet-screened-out particles } \\
\text { with size larger than } 100 \mathrm{~mm}\end{array}$ \\
\hline & & $2.34 \times 10^{-8} \sim 4.89 \times 10^{-8}$ & $\varphi 430 \times 440$ & $\begin{array}{l}\text { Full grading with maximum } \\
\text { particle size of } 150 \mathrm{~mm}\end{array}$ \\
\hline Experiment 5 [17] & 28 & $3.13 \times 10^{-8}$ (abnormal CSG) & $450 \times 450 \times 450$ & $\begin{array}{l}\text { Full grading with maximum } \\
\text { particle size of } 250 \mathrm{~mm}\end{array}$ \\
\hline
\end{tabular}

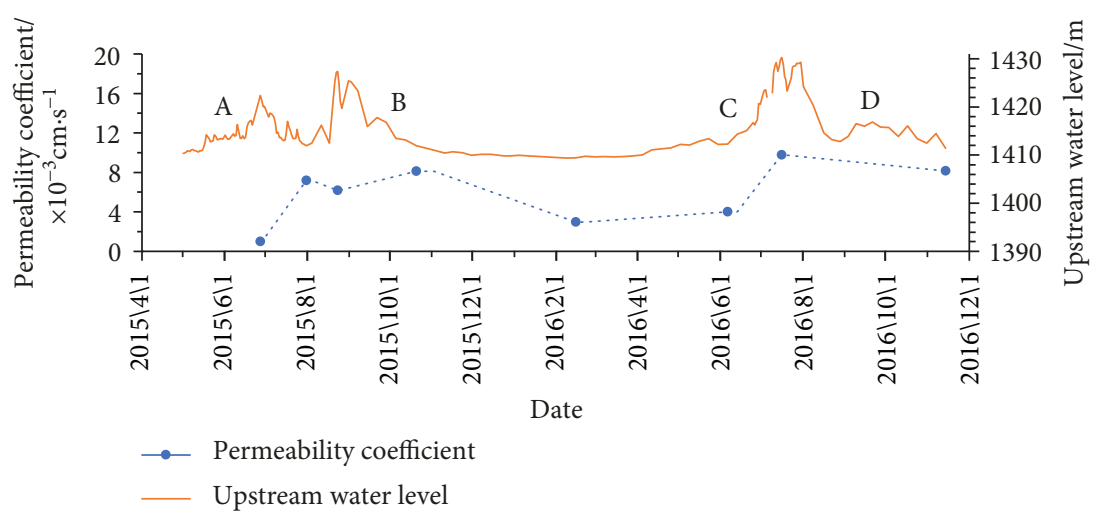

FIGURE 7: Variations in the permeability coefficient for normal CSG.

achieve uniformity of compaction and local cellular segregation can arise. Thus, it can be difficult to achieve the laboratory-based high antiseepage performance in practice.

The permeability coefficients obtained by inversion changed according to the time of seepage, with the permeability coefficient for the normal CSG material being at a level of $10^{-3} \mathrm{~cm} / \mathrm{s}$ and the permeability coefficient for abnormal CSG being at a level of $10^{-5} \sim 10^{-4} \mathrm{~cm} / \mathrm{s}$. Figures 7 and 8 show the change process diagram for the permeability coefficients of CSG and abnormal CSG. Under the action of long-term seepage, the permeability coefficient of the CSG increased after water storage, with its peak value occurring during the flood season in the first year. It then gradually reduced. A second peak value occurred during the flood season in the second year. After the first peak value, the change amplitude of the permeability coefficients of the abnormal CSG in the 


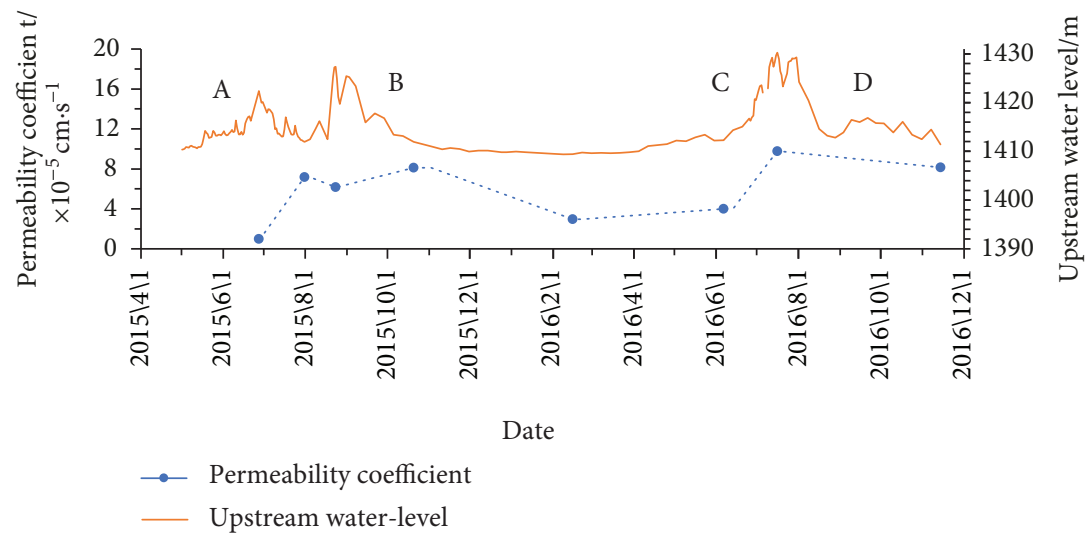

FIgURE 8: Variations in the permeability coefficient for abnormal CSG.

antiseepage layer was small. The permeability coefficients in the later period were about one order of magnitude larger than they were in the initial period, and the value remains relatively stable. However, the variation in the permeability coefficients for normal CSG is relatively large. After analysis, the change in the permeability coefficients for CSG materials according to seepage time was seen to have the following two causes:

(1) Expansion of seepage channels under high water pressure. The anticracking properties of CSG materials are weak, and microcracks propagated during the rolling of the layer for the dam, putting the material in a weak condition for resisting water pressure and temperature-related seepage. According to feedback from the Dahuaqiao cofferdam construction site, the abnormal CSG cement paste was not easy to spread and a noticeable slurry surface layer appeared on the rolling layer. As the slurry formed at a late stage, this may have become the actual surface with consequently weak antiseepage performance. Analysis of the temperature field for the cofferdam shows that the temperature difference between the inside and outside of the dam near the upstream face during the flood season of 2015 was fairly large. This may have caused local cracking of the antiseepage layer and the inner surface. Surfaces with weak antiseepage performance or cracks caused by temperature stress would have been prone to opening up and extending under high water pressure during the flood season (especially the flood season in the first year). This would have weakened the antiseepage effect and increased the permeability coefficient.

Comparing the two kinds of material, the effect on the abnormal CSG in the antiseepage layer was larger, meaning that the increasing amplitude of the permeability coefficient was bigger than it was in the initial seepage stage after the flood season in the first year. The permeability coefficient in the $A B$ section increased to a level of nearly $10^{-4} \mathrm{~cm} / \mathrm{s}$ from $10^{-5} \mathrm{~cm} / \mathrm{s}$.
(2) The self-healing phenomenon. Previous experiments have confirmed that normal and rolling concrete has some self-healing capabilities. Fang et al. [18] found that when the permeability gradient was less than an allowed value, extending the seepage duration time resulted in the permeability coefficient of the concrete gradually increasing to a maximum value at first, but then gradually reducing and staying at a certain value. Sheng et al [19] found in experiments that the water-cement ratio can be one of the key factors, depending on when a permeability coefficient peak value for the concrete appears. Concrete with a larger water-cement ratio has a relatively large change rate for its permeability coefficient when tested under the same erosion conditions, and its peak value occurs quickly. After adding a small dose of coal ash to the concrete, it shows a large reduction rate for its permeability coefficient. In view of the secondary hydration action relating to coal ash, the permeability coefficient could even reduce to a level below its initial value.

Experiments reported in [7] proved that CSG exhibits similar self-healing properties, with the obtained permeability coefficient changing over time. At the initial stage of a first period, the permeability coefficient was relatively large. At the latter stage of a second period (basically after seepage for 120 days), the average permeability coefficient had reduced by about $60 \%$ from its initial value. Analysis of the dissolution mechanism once again proved that the anticorrosion performance of CSG does not continue to get worse, but rather stabilizes after a certain amount of time. The effect of corrosion on the porosity of mortar is small, so it was deduced that the seepage path was mainly through weak areas such as the interface.

If we look at the $\mathrm{BC}$ section, we can see that, when the upstream water level was relatively stable, the permeability coefficient for the two kinds of materials gradually decreased as the seepage duration time increased. Abnormal CSG uses more glue materials, and its water-binder ratio is smaller, so both the rate of decrease and the amplitude of the permeability coefficient are small here as well, with the permeability coefficient remaining relatively stable. The 
TABLE 3: Results analysis of seepage for various water-level characteristics.

\begin{tabular}{|c|c|c|c|c|c|c|}
\hline & $\begin{array}{l}\text { Upstream water } \\
\text { level }(\mathrm{m})\end{array}$ & $\begin{array}{c}\text { Water-head beyond } \\
\text { the antiseepage } \\
\text { layer }(\mathrm{m})\end{array}$ & $\begin{array}{c}\text { Cutting water-head } \\
\text { of the antiseepage } \\
\text { layer }(\mathrm{m})\end{array}$ & $\begin{array}{c}\text { Percentage } \\
\text { of cutting } \\
\text { water-head (\%) }\end{array}$ & $\begin{array}{l}\text { Seepage } \\
\text { gradient }\end{array}$ & Water-level characteristic \\
\hline 1 & 1422.38 & 1402.52 & 19.86 & 39.42 & 13.40 & $\begin{array}{l}\text { Largest water-level difference } \\
\text { between upstream and } \\
\text { downstream in } 2015\end{array}$ \\
\hline 2 & 1427.36 & 1414.49 & 12.87 & 23.25 & 10.51 & $\begin{array}{l}\text { Highest upstream water } \\
\text { level in } 2015\end{array}$ \\
\hline 3 & 1409.43 & 1401.09 & 8.34 & 22.28 & 5.56 & Low water level \\
\hline 4 & 1422.10 & 1400.89 & 21.21 & 42.34 & 13.96 & $\begin{array}{l}\text { Largest water-level difference } \\
\text { between upstream and } \\
\text { downstream in } 2016\end{array}$ \\
\hline 5 & 1430.26 & 1419.2 & 11.06 & 18.98 & 9.76 & $\begin{array}{l}\text { Highest upstream water } \\
\text { level in } 2016\end{array}$ \\
\hline
\end{tabular}

variation amplitude for the permeability coefficient of the normal CSG was larger, with its value reducing almost to the initial permeability coefficient value. For the CD section in the flood season during the second year, the permeability coefficients for both kinds of material increased under the action of high water pressure, then the permeability coefficient for the normal CSG reduced quickly. Thus, compared to the abnormal CSG, which was relatively close to the concrete, the self-healing ability for the normal CSG was stronger, helping to maintain the seepage stability of the dam.

5.2. Antiseepage Results for the Antiseepage Layer. Table 3 shows the calculated results for the antiseepage layer across various water-level characteristics. According to the dynamic change law for the permeability coefficient of abnormal CSG, after the flood season in 2015, the antiseepage effect of the upstream antiseepage layer of the cofferdam significantly diminished, when compared to before the flood season. After this, the antiseepage effect remained more or less stable in relation to variations in the water level and the change amplitude was small. When the difference of water level between upstream and downstream was at its maximum, the cutting action of the antiseepage layer on the upstream water-head was at its strongest and the seepage gradient in the antiseepage layer was at its largest. After the flood season and in the dry season, the cutting action of the antiseepage layer on the upstream water-head weakened and the seepage gradient in the antiseepage layer decreased. Comparing 2015 with 2016, the reduction effect of the antiseepage layer on the water-head slightly decreased. Comparative results gathered under the same conditions showed that, after a year of seepage, the antiseepage effect of the antiseepage layer was slightly reduced, but the change amplitude was small. Thus, the antiseepage properties of the abnormal CSG layer did not suffer any further obvious deterioration.

To investigate the antiseepage effects of the cofferdam during certain operating period water-level characteristics, we chose the working conditions that covered periods with the highest water level and the largest water-level difference. Under the highest water-level conditions, an uplift effect from the downstream water- level and flow over the crest raised the infiltration line and the cutting head effect of the antiseepage layer weakened. The upstream water level was $1430.26 \mathrm{~m}$ in 2016 , and the cutting percentage at the water-head was $18.98 \%$. The maximum seepage gradient of the antiseepage layer was 9.76. Looking at the maximum difference between the upstream and downstream water levels, when the upstream water level was $1422.10 \mathrm{~m}$ in 2016 , the cutting percentage of the water-head was $42.34 \%$. Here, the maximum seepage gradient of the antiseepage layer was 13.96 .

The calculated seepage discharge according to different water levels is shown in Figure 9. It can be seen that the effect of the upstream water level was significant. Before the flood season of 2015, the seepage discharge was small, but after the flood season there was an evident change of seepage discharge in relation to water level. The seepage discharge for the dry season was relatively stable. At the highest water level, the seepage discharge was $19.4 \mathrm{~L} / \mathrm{s}$ in 2015 and $32.5 \mathrm{~L} / \mathrm{s}$ in 2016. In the dry seasons for these two years, the seepage discharge was about $11 \sim 13 \mathrm{~L} / \mathrm{s}$.

5.3. The Seepage Properties of the Dam. As can be seen from the flow net diagram in Figure 10, for the water-level characteristics of the Dahuaqiao cofferdam, the water-head was chiefly affected by the upstream water level. The water-head inside the dam gradually decreased in the direction of the river from upstream to downstream. Due to the lack of drainage facilities, the infiltration line inside the dam was very high, with the infiltration line at low water-level still being almost half the height of the dam body and changing according to changes in the upstream water level.

During its operational period, the operating conditions at the highest water level and the maximum difference between the upstream and downstream water level were examined to investigate any adverse factors influencing the seepage field. At the highest water level, the downstream water level was also high, so that the downstream water level and water flow over the dam crest could infiltrate the dam. The water infiltrating from the dam crest and the downstream face could raise the infiltration line inside the dam body. In 2016, when 


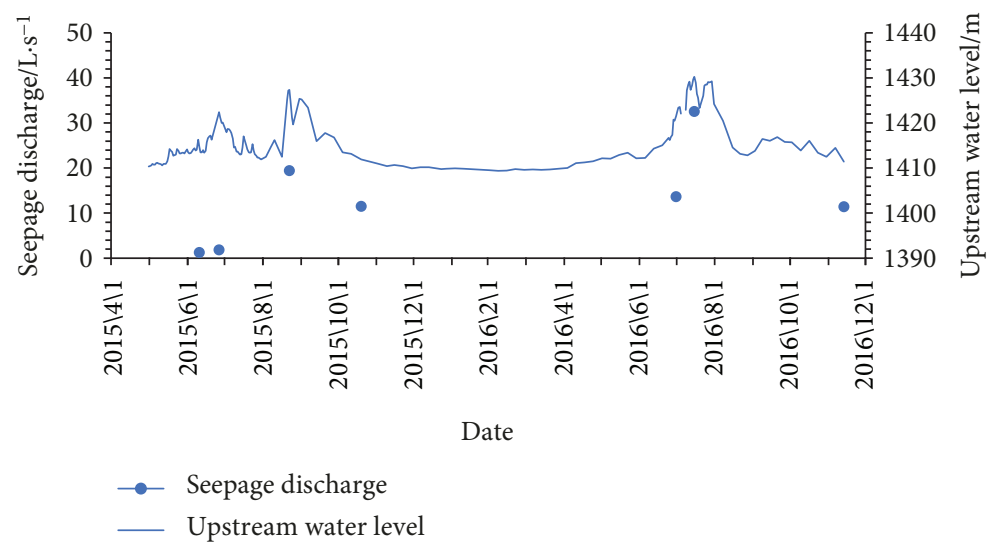

FIgURE 9: Variations in the seepage discharge process for the dam body over seepage time.

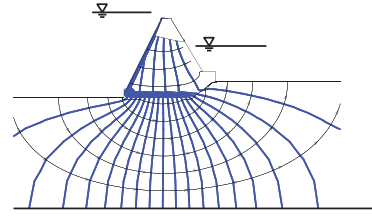

(a)

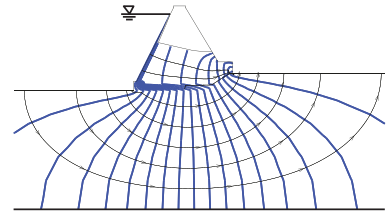

(b)

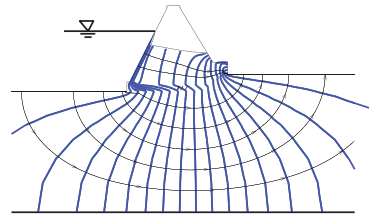

(c)

Figure 10: Flow net diagram of the dam according to various water-level characteristics. (a) The highest water level, (b) the maximum difference in water level between upstream and downstream, and (c) the lowest water level.
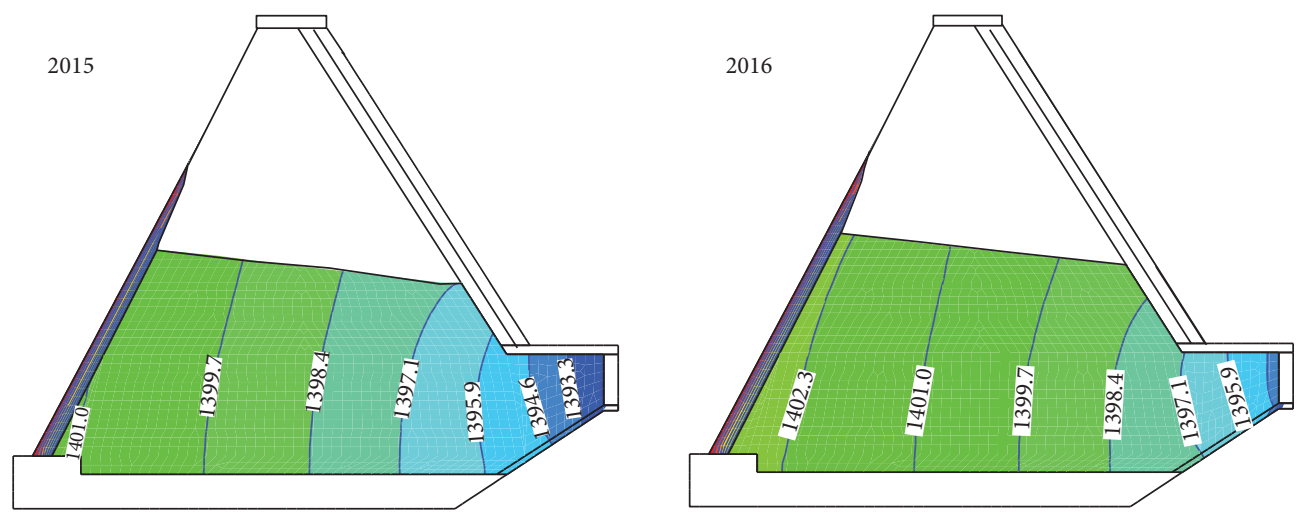

Figure 11: Comparison of the equipotential line inside the dam (unit: meters).

the upstream water level was $1430.26 \mathrm{~m}$, the infiltration line inside the dam body had a height of $1419 \mathrm{~m}$, which was only $7 \mathrm{~m}$ from the dam crest. A high infiltration line is not good for the seepage stability of a dam. Looking at the maximum water-level difference between upstream and downstream, there was a large seepage gradient below the egress points in the downstream face. For both CSG materials, the partial seepage gradient surpassed 0.6 in 2015 and 2016. At this point, the upstream antiseepage layer had a seepage gradient of about 20. This kind of seepage gradient for the antiseepage layer and an excessive partial seepage gradient are bad for the stability of the seepage field inside a dam.

One of the main questions regarding the durability of the CSG material is whether seepage failure is occurring over longer-term seepage conditions and under the corrosive effect of water pressure. During the operational period for the cofferdam, the moments of steady seepage under the same conditions after the flood seasons of 2015 and 2016 were compared to see whether the seepage properties had changed or not after the seepage process had been ongoing for at least a year. Comparisons of the seepage properties can be seen in Figure 11 and Table 4. We can observe here that, after seepage for one year, the cutting water-head in the antiseepage layer had decreased and the seepage gradient had reduced. The seepage gradient inside the dam, however, remained the same, with the seepage discharge slightly decreasing. Over the increased scale for the seepage process, the antiseepage effect of the antiseepage layer made of 
TABLE 4: Comparison of the seepage properties of the dam body after operating for one year.

\begin{tabular}{ccccccc}
\hline Year & $\begin{array}{c}\text { Upstream water level } \\
(\mathrm{m})\end{array}$ & $\begin{array}{c}\text { Cutting head for antiseepage } \\
\text { layer }(\mathrm{m})\end{array}$ & $\begin{array}{c}\text { Cutting water-head } \\
\text { percentage }(\%)\end{array}$ & $\begin{array}{c}\text { Seepage gradient } \\
\text { Abnormal } \\
\text { CSG }\end{array}$ & $\begin{array}{c}\text { Seepage discharge } \\
(\mathrm{L} / \mathrm{s})\end{array}$ \\
\hline 2015 & 1411.49 & 10.57 & 26.77 & 7.31 & 0.13 & 11.42 \\
2016 & 1411.4 & 8.93 & 22.67 & 6.03 & 0.13 & 11.33 \\
\hline
\end{tabular}

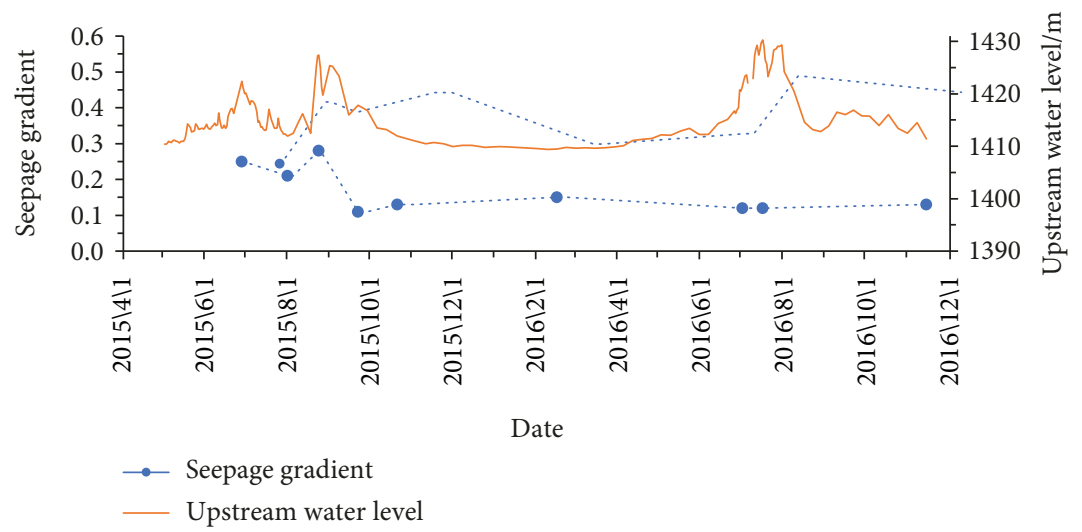

Figure 12: Changes in the CSG seepage gradient inside the dam over time.

abnormal CSG was reduced slightly, causing an overall uplift of the infiltration line, but the flow rate decreased slightly, reducing the seepage discharge from the dam body.

After the end of the flood season in 2015, the seepage characteristics of the dam body remained relatively stable and the change of seepage gradient inside the dam was relatively small (see Figure 12). Although the infiltration line inside the dam remained high, the seepage discharge was small. In the dry season, the seepage discharge was approximately $11 \sim 13 \mathrm{~L} / \mathrm{s}$, and in the flood season it was about $30 \mathrm{~L} /$ s. After the seepage process had lasted for a year, the seepage properties of the dam body had only changed a little and the seepage situation within the dam was not significantly worse. We can conclude from this that CSG materials do meet the required antiseepage and anticorrosion capacities needed for hydraulic engineering.

\section{Discussion}

(1) The actual permeability coefficient differed significantly from the values obtained in domestic laboratory tests.

The permeability coefficient for normal CSG obtained by the inversion method was at a level of $10^{-3} \mathrm{~cm} / \mathrm{s}$. This differed significantly from the values obtained in domestic laboratory tests. This was largely because the usual methods used for testing concrete are not suitable for CSG-type materials, making it hard to get any real parameters. There are three aspects to this: (a) in current domestic test procedures for hydraulic concrete, the regulations specify that the minimum length of the side of concrete specimens for laboratory antiseepage tests should not be less than 3 times the maximum size of the aggregates. If it was not so, the largest aggregates need to be filtered out using a wet sieving method. For concrete, the controls relating to the grade and maximum size of particles are strict and the grading of specimens is basically the same as the process for filtering out large aggregates. However, controls on the maximum aggregate size for CSG materials are not at all strict. So, after the larger particle in the aggregate of the specimen has been filtered out, a scale effect is generated. In addition, as a result of the low dosage of cementitious materials, the original undesirable overall character of the aggregate can be changed for the good. This has a large impact on the permeability measurements. (b) In the test specifications, there is a requirement that specimens be mixed evenly with the mixer and maintained at a constant temperature and humidity. The construction and maintenance measures for concrete dams are strict. However, the construction and maintenance measures for CSG dams are not and it is easy to have a large aggregate separation. These aggregates are prone to concentrating at the level boundary, creating a weakness where seepage can occur. (c) The standard test method involves stepwise pressurization of the material. Concrete materials have good compactness and a high degree of strength, but the strength of CSG materials is low and the cementation density is not high. In gradual pressurization processes, the original porosity and microcracks with high permeability were compacted, artificially enhancing the antiseepage abilities obtained by the tests.

A second issue here is that, because of the extensive variability in selection, processing, and construction technologies, the discreteness of the antiseepage 
properties of actual CSG materials is large and it is difficult to reflect this in laboratory tests. The requirements placed on colloidal gravel material regarding the quality and gradation of aggregates are low, and there is no particular stipulation regarding the adjustment of aggregate gradation or its cleaning. The dosage of cementitious material is small, and the water consumption and coal ash content can fluctuate within a certain range. As a result, the mortar margin and cementation strength of partial CSG material with good gradation can appear to be better, while the mortar margin and cementation strength of other CSG materials with poor gradation will seem poor. The Dahuaqiao CSG dam adopted a thin-layer rolling and filling method, and the construction requirements were relaxed. A certain degree of aggregate separation was allowed, and the mixing process was simplified, with the layer face treatment being lowered to its minimum level. It was impossible to avoid uneven spreading and concrete aggregate separation during the construction, so locally concentrated seepage channels were formed.

Finally, because the tensile strength of the material is low, temperature cracks generated under the conditions of actual construction can cause a decrease in the antiseepage capability of CSG when compared to laboratory tests. It is generally believed that, as CSG uses a small amount of cementitious materials and its hydration heat is low, there is no temperature control problem. However, adjustment of the dosage of cement, high temperatures, and poor heat dissipation between the layers during the actual construction process meant that the maximum measured temperature at the Dahuaqiao cofferdam was above $40^{\circ} \mathrm{C}$. The maximum temperature appreciation was $17.8^{\circ} \mathrm{C}$, which was obviously larger than the temperature appreciation present in the laboratory tests.

(2) The effect of CSG material corrosion on cofferdam safety

The seepage and corrosion mechanism for CSG materials, like concrete, depends on the permeability of the cement slurry, its internal pore characteristics, and its structural compactness. Experiments have shown that, for the same specimen, with an increase in age, the daily dissolution of $\mathrm{Ca}^{2+}$ will gradually reduce until it reaches a relatively stable condition where there is basically no longer any dissolution. This has also been called a "self-healing phenomenon." In the experiments, for specimens with a long curing age ( 1 year or more), there was no $\mathrm{Ca}^{2+}$ dissolution even if the seepage pressure was increased. After the osmotic corrosion of pressurized water, the strength of the CSG material did decrease. However this reduction was caused not only by $\mathrm{Ca}^{2+}$ dissolution itself but also by the pores being forced to fill under the water pressure. In that case, a stockyard with excellent aggregate gradation is needed to be able to select CSG materials with the best density and antiseepage performance during the construction process.

From the monitoring data and calculated results for the Dahuaqiao cofferdam, the seepage condition of the CSG inside the dam and abnormal CSG in the antiseepage layer was stable during the operating period, with their permeability only decreasing very slightly. After the operating period, core tests showed that there was no evident decrease in the material strength. In that case, for cofferdams that are being used for 2-3 years, material corrosion will not have a significantly adverse impact on cofferdam safety and the use of abnormal CSG as an antiseepage layer will fully meet the antiseepage requirements of a cofferdam.

(3) No dam drainage was required upstream of the cofferdam

Speed and simplification of the construction process is a key advantage of CSG dams. However, it was not possible to avoid an increase in crossoperational difficulty when coupling the drainage pipes and the drainage gallery after the antiseepage layer. The burying of the drainage pipes interfered a lot with the construction of the antiseepage layer. Most conventional dams need to establish the dam body drainage to reduce the internal seepage line. However, for CSG dams, especially CSG cofferdams, the high stability margin of the symmetrical trapezoid means that a high internal seepage line will not cause dam instability. During its operation, corrosion had no significant adverse impact on safety at the Dahuaqiao cofferdam. From the monitoring data and calculated results, although the seepage line was high, the seepage discharge was small and, combined with a small flow rate inside the dam, a small seepage gradient, stable seepage conditions, and no seepage failures, it can be concluded that these various traits are enough to completely satisfy the functional requirements for a cofferdam. To date, most cofferdams do not have dam body drainage and there is even a permanent dam with no dam body drainage in Japan. In that case, for cofferdams, consideration of the dam body drainage is unnecessary and even for permanent dams, the feasibility of removing the dam body drainage should be further explored and the emphasis placed instead upon ensuring the effectiveness of the antiseepage layer.

(4) The fundamental approach to antiseepage and the drainage of cofferdams could be simplified.

When the dam foundation antiseepage and drainage were not set, the uplift pressure at the dam foundation changed almost linearly with the upstream and downstream heads. The symmetrical trapezoid shape of CSG cofferdams provides them with a large volume and weight. Their capacity to use the upstream 
water weight is large, as is the safety margin for their antislide stability. After calculation of the antislide stability at the Dahuaqiao cofferdam, it was found that, under the maximum water level conditions during its operational period, the stability coefficient at the minimum point of the dam foundation toe was greater than 3 . The stability coefficients at the minimum point of the other sliding faces were all above 5. As only a small part inside the dam that was close to the downstream also had a sliding direction towards the downstream, most of the layer surfaces possessed only a small shearing strength value or were pointed towards the upstream. The calculated antisliding stability safety coefficient for an overall layer surface was very large. In addition, CSG cofferdams have a very wide dam foundation. The seepage path along the dam surface is long, and the seepage gradient at the dam foundation near the dam toe is small. In that case, the seepage safety of the dam foundations presents no particular problem.

\section{Conclusions}

Using measured time series data from water-head measuring sites at the Dahuaqiao CSG cofferdam, we undertook an inversion analysis of the unsteady seepage field for the dam at different times. The permeability coefficients for normal and abnormal CSG were inverted, and the seepage field characteristics of the CSG dam were analyzed. On the basis of this, we arrived at the following conclusions, which include indications of how the CSG dam design theory might be further developed and improved.

(1) The inversion results for the Dahuaqiao cofferdam and related material tests show that the permeability coefficient for CSG can reveal a similar self-healing capacity to concrete. This is beneficial for the seepage stability of a CSG dam.

(2) The permeability coefficient for CSG obtained by the inversion method differed significantly from the values obtained in domestic laboratory tests. The standard laboratory test method for concrete was not suitable for CSG materials, and the real parameters could not be obtained. The high discreteness of the material's seepage performance and the effect of microcracks caused by temperature are all factors that may have led to a significantly reduced antiseepage performance when compared to the laboratory experiments. Material test methods could be much improved by taking properly into account the characteristics of CSG materials and CSG dams.

(3) During the operational period of the Dahuaqiao cofferdam, the seepage line was high, but the actual seepage was small and the permeability proved to be stable. Nor did the seepage behavior of the dam body deteriorate significantly under the long-term effects of water pressure. The results indicate that CSG materials have an ability to resist seepage and corrosion, with abnormal CSG being able to meet the needs of cofferdams as an antiseepage layer. It was also found that dam body drainage and dam foundation antiseepage and drainage do not need to be incorporated into cofferdams. This study may thus also provide the basis for the further exploration of how to simplify dam structures, including permanent dams.

\section{Data Availability}

The data used to support the findings of this study are available from the corresponding author upon request.

\section{Conflicts of Interest}

The authors declare that there are no conflicts of interest regarding the publication of this paper.

\section{References}

[1] P. Londe and M. Lino, "The faced symmetrical Hardfill dam: a new concept for RCC," Water Power and Dam Construction, vol. 44, no. 2, pp. 19-24, 1992.

[2] D. G. Coumoulos and T. P. Koryalos, "Lean RCC damslaboratory testing methods and quality control procedure during construction," in Proceedings 4th International Symposium on Roller Compacted Concrete Dams, pp. 233-238, Madrid, Spain, 2003.

[3] S. Batmaz, "Cindere dam-107 m high roller compacted hardfill dam (RCHD) in Turkey," in Proceedings 4th International Symposium on Roller Compacted Concrete Dams, pp. 121126, Madrid, Spain, 2003.

[4] J. Wang, "Design and research on the cemented sand-gravel dam for the Shoukoubu reservoir," Shanxi Hydrotechnics, no. 2, pp. 1-4, 2015.

[5] J. Jia, M. Lino, F. Jin, and C. Zheng, "The cemented material dam: a new, environmentally friendly type of dam," Engineering, vol. 2, no. 4, pp. 490-497, 2016.

[6] X. Chen, Z. Li, Y. L. He, and K. Fang, "Leaching corrosion of Hardfill dam materials," Engineering Journal of Wuhan University, vol. 42, no. 1, pp. 42-45, 2009.

[7] W. Feng, Studies on Cemented Sand and Gravel Dam Material and its Application, China Institute of Water Resources and Hydropower Research, Beijing, China, 2013.

[8] S. Shao, "Incompressible SPH flow model for wave interactions with porous media," Coastal Engineering, vol. 57, no. 3, pp. 304-316, 2010.

[9] W. Li, Y.-f. Ch, and R. Hu, "Back analysis of rock permeability with consideration of transient flow process," Chinese Journal of Rock Mechanics and Engineering, vol. 34, no. 2, pp. 362-373, 2015.

[10] W. Liu, Y. He, and P. Yin, "Numerical analysis of Hardfill dam's seepage flow field," Engineering Journal of Wuhan University, vol. 41, no. 2, pp. 5-10, 2008.

[11] A. M. Yanmaz and O. I. Sezgin, "Evaluation study on the instrumentation system of Cindere dam," Journal of Performance of Constructed Facilities, vol. 23, no. 6, pp. 415-422, 2009. 
[12] G. Ciwei, Seepage Computation Principle and Application, China building material industry publishing house, Beijing, China, 2000.

[13] T. Hirose, T. Fujisawa, H. Kawasaki, M. Kondo, D. Hirayama, and T. Sasaki, "Design concept of trapezoid-shaped CSG dam," in Proceedings 4th International Symposium on Roller Compacted Concrete Dams, pp. 457-464, Madrid, Spain, 2003.

[14] Y. He, The Investigation Report of Hardfill Dam in Fujian Province, State Key Laboratory of Water Resources and Hydropower Engineering Science of Wuhan University, 2008.

[15] Y. He, SL 678-2014 Technical Guideline for Cemented Granular Material Dams, China Water \& Power Press, Beijing, China, 2014.

[16] J. Jia, N. Liu, C. Zheng, F. Ma, Z. Du, and Y. Wang, "Studies on cemented material dams and its application," Journal of Hydraulic Engineering, vol. 47, no. 3, pp. 315-323, 2016.

[17] Y. He, Research Report on the Overflow Cofferdam Upstream of the Dahuaqiao Hydropower Station on the Lantsang River in Yunnan Province, Power China Beijing Engineering Corporation Limited, 2014.

[18] K. Fang, Y. Ruan, and L. Zeng, "A study on permissive permeability gradient of concrete," Journal of Hydroelectric Engineering, vol. 2, pp. 8-16, 2000.

[19] J. Sheng, C. Jia, Y. Zhang, M. Zhan, and J. Li, "Experimental study of seepage inflow erosion processes in concrete," Journal of Hydroelectric Engineering, vol. 32, no. 6, pp. 216-221, 2013. 


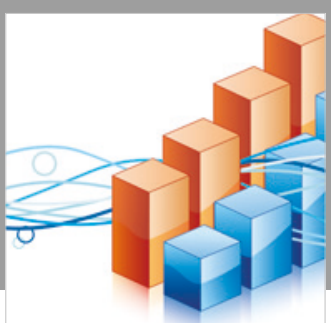

Advances in

Operations Research

\section{-n-m}
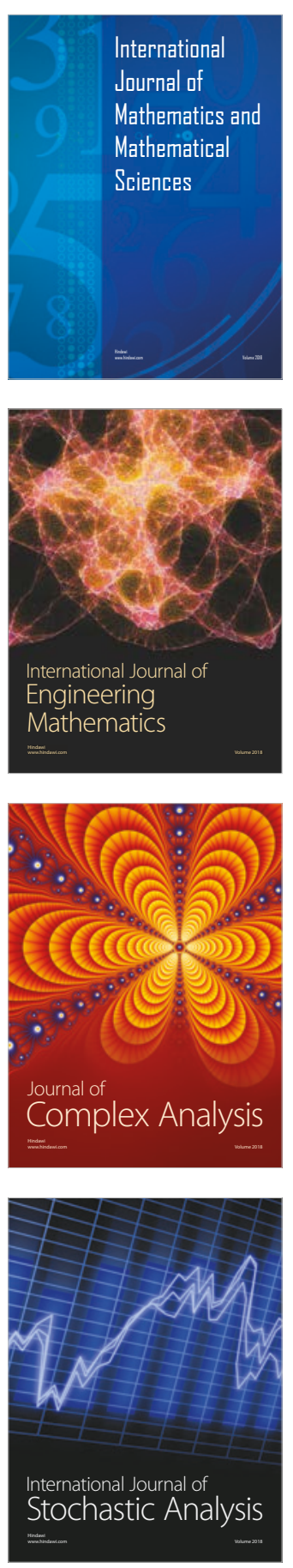
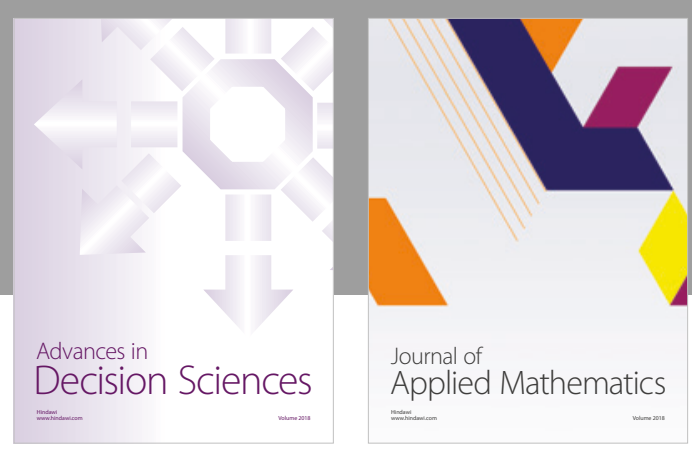

Journal of

Applied Mathematics
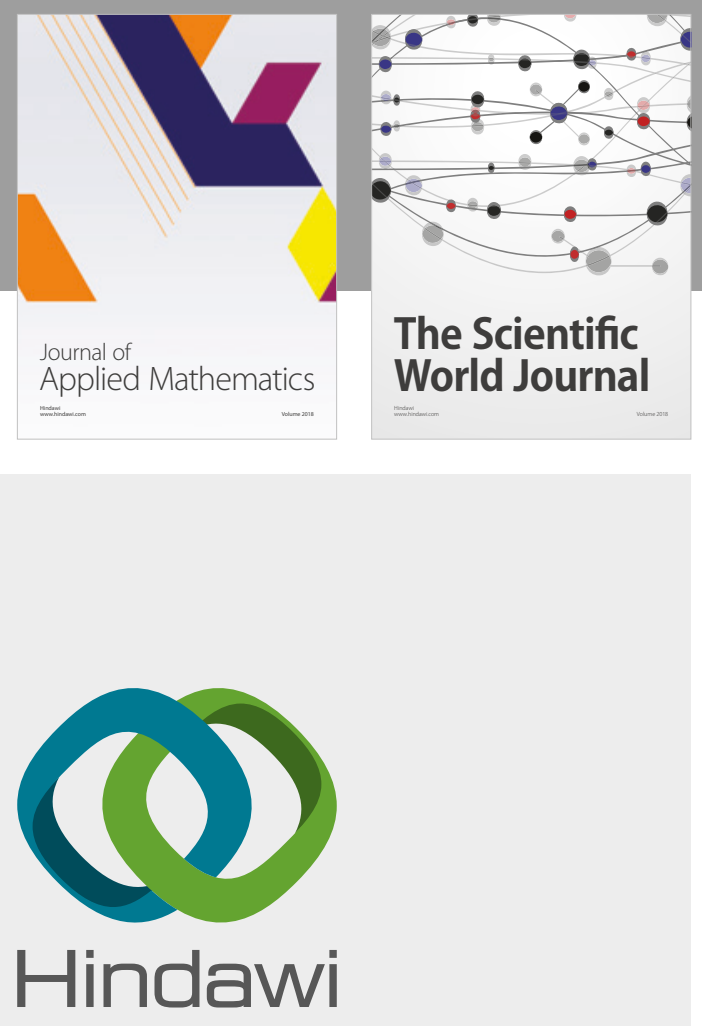

Submit your manuscripts at

www.hindawi.com

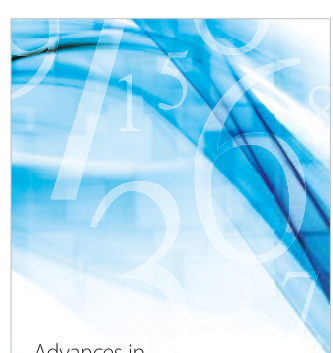

Advances in
Numerical Analysis
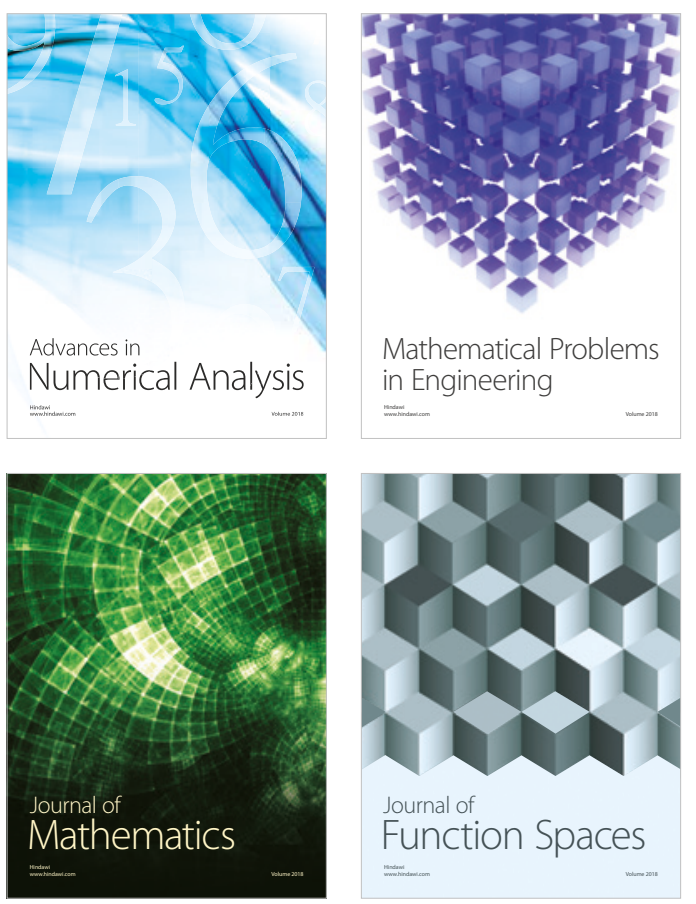

Mathematical Problems in Engineering

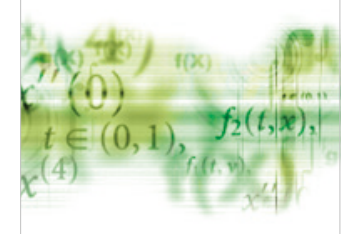

International Journal of

Differential Equations

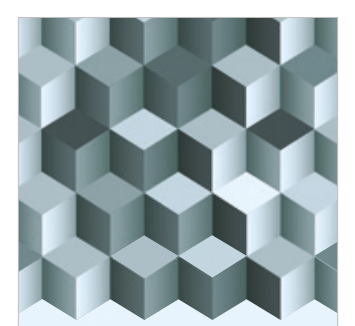

Journal of

Function Spaces
The Scientific

World Journal

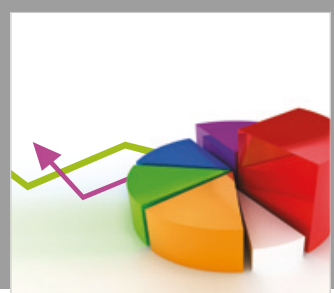

Journal of

Probability and Statistics
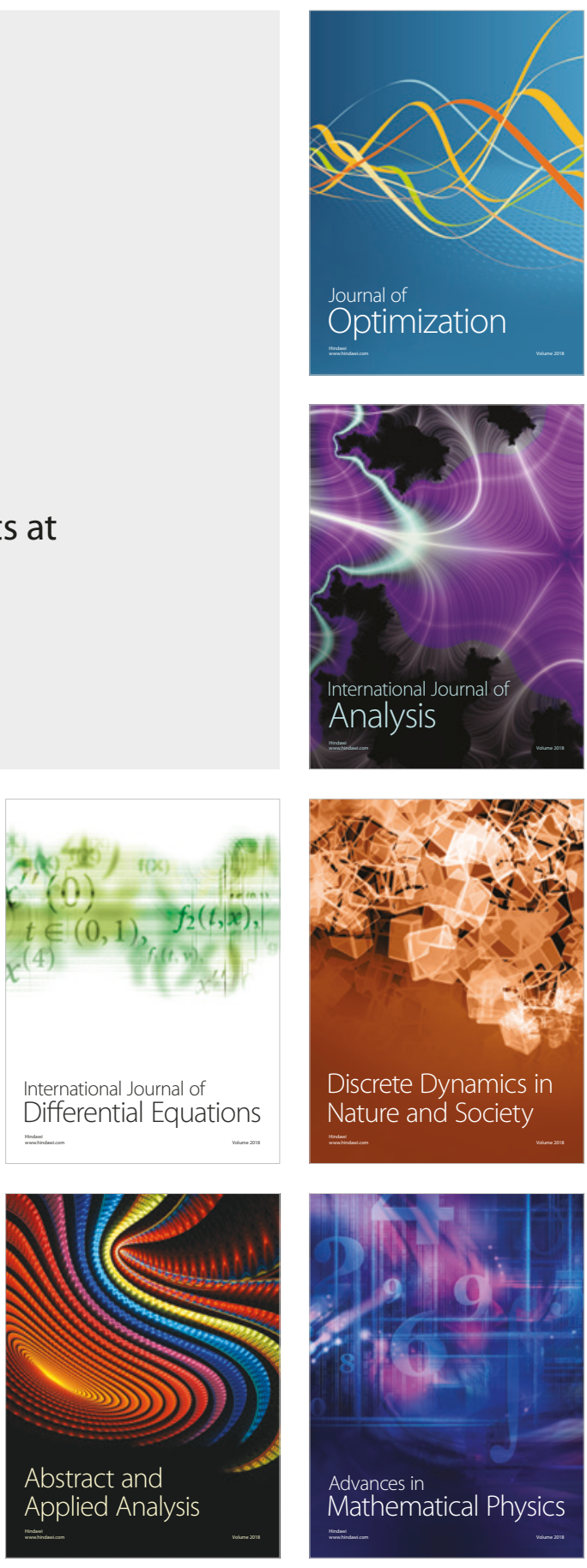